\title{
In situ degradability of feed ingredients at two proportions of concentrate
}

\author{
HV Petit * \\ Experimental Farm, Agriculture Canada, La Pocatière, Quebec GOR 1Z0, Canada
}

(Received 6 February 1992; accepted 30 March 1992)

\begin{abstract}
Summary - Protein, energy and fiber sources were incubated in nylon bags in the rumen of 4 cows to determine the effect of proportion of concentrate on the effective degradability of DM and protein at 3 theoretical solid outflow rates. Two of the cows were fed a low level of concentrate $(20 \%$ of total dry matter, DM) and the other 2 a medium level ( $40 \%$ of total DM). In general, with the use of theoretical flow constants for simulation of degradability measurement, proportion of concentrate had no effect on the effective degradability of DM while effective degradability of protein of different ingredients decreased as the proportion of concentrate increased. Effective degradability of protein of the energy sources was not affected by proportion of concentrate in the diet. The data suggest that effective degradability of DM and protein of various ingredients calculated using theoretical flow constants could be affected by the proportion of concentrate fed to dairy cows.
\end{abstract}

nylon bag / degradability / protein / concentrate

Résumé - Dégradabilité in situ de quelques ingrédients mesurée à deux niveaux d'alimentation du concentré. Des sources de protéine, d'énergie et de fibre ont été incubées dans des sachets de nylon dans le rumen de 4 vaches afin de déterminer l'effet du pourcentage de concentré de la ration sur la dégradabilité de la matière sèche et de la protéine mesurée à 3 taux de passage théorique. Deux vaches ont reçu un bas niveau de concentré (20\% de la matière sèche) et deux autres, un niveau moyen ( $40 \%$ de la matière sèche). En général, le niveau de concentré n'a eu aucun effet sur la dégradabilité de la matière sèche; la dégradabilité de la protéine des sources de protéine a toutefois diminué avec l'augmentation du niveau de concentré alors que celle des sources d'énergie n'a pas été affectée. Les résultats suggèrent que la dégradabilité de la matière sèche et de la protéine calculée en utilisant des taux de passage théoriques peut être affectée par la quantité de concentré contenue dans la ration des vaches laitières.

sachet de nylon / dégradabilité / protéine / niveau d'alimentation

\section{INTRODUCTION}

Degradability of protein within a given feed ingredient can be quite variable. Conditions such as type of dietary ingredients and concentration of nutrients in the diet have been found to modify protein degradability (Lindberg, 1985). Compared to a diet based on hay, Ganev et al (1979) found that protein degradability of plant products decreased when a barley-based diet was fed, while that of fishmeal was

\footnotetext{
* Contribution No 368
} 
not affected. In general, protein degradability of protein supplements decreases with increasing level of grain in the diet (Loerch et al, 1983; Weakley et al, 1983) but this is not always the case (Lindberg, 1981). Little information is available on effect of proportion of concentrate in the diet on protein degradability of different groups of feed ingredients commonly fed to dairy cows, since only protein sources have been used in most experiments (Lindberg, 1985). Increased knowledge of these effects would allow more precision in diet formulation for dairy cows since the concentrate-to-forage ratio of diets varies according to milk production and lactation stage. Moreover, the effective degradability of protein is often calculated using theoretical values of solid outflow rates $(k)$ representative of low, medium and high feed intakes (Agricultural Research Council, 1984) but it is not known how the concentrate-to-forage ratio could affect those theoretical calculations for different groups of feed ingredients. The objective of this study was to determine if degradability of dry matter and protein in different feed ingredients (sources of energy, protein and fiber) is affected by the level of concentrate contained in the diet of lactating dairy cows; this was done by sirriulating different $k$ values to calculate theoretical degradability.

\section{MATERIALS AND METHODS}

\section{Animals and feeding}

Four multiparous lactating Holstein cows each fitted with a ruminal cannula were assigned to 2 groups of 2 animals each in a completely randomized design. Cows produced an average of $23.9 \mathrm{~kg}$ of milk per day and were $58 \mathrm{~d}$ in lactation. One group received on a dry matter (DM) basis a low level of concentrate (LC) consisting of $20 \%$ high moisture ear corn and $80 \%$ alfalfa silage, and the other was fed a medium level of concentrate (MC) with $40 \%$ high moisture ear corn and $60 \%$ alfalfa silage on a DM basis. Alfalfa silage and high moisture ear corn contained 52.4 and $62.3 \% \mathrm{DM}$, and 2.39 and $1.43 \%$ total $\mathrm{N}$ (TN) on a DM basis, respectively. Percentage of crude protein (CP) in the diet was 12.5 and $13.7 \%$ for MC and LC, respectively. Diets were fed ad libitum once a day, and animals were allowed 3 wk of adaptation before the nylon bag trial was initiated. Animals consumed about 20 $\mathrm{kg}$ DM per day during the experiment. Samples of feed ingredients were obtained in the physical form used in commercial diet formulation (ground) and were incubated as received (table 1). Classes of feed ingredients included protein supplement (6 samples), energy (4 samples) and fiber sources (1 sample). According to Church (1984), feed ingredients were arbitrarily defined as protein sources when CP was greater than $20 \%$, energy sources when the product had less than $20 \%$ CP and was a cereal grain or one of its milling by-products, and fibre source (or roughage) was used for dry crop residue. Protein sources were either of animal or plant origin, while energy and fiber sources were all of plant origin.

\section{In sacco procedure}

Bags used for incubation were $9 \times 17 \mathrm{~cm}$ in size and were sewn with rounded corners to allow

Table I. Chemical composition of the different feed ingredients incubated in nylon bags.

\begin{tabular}{|c|c|c|c|}
\hline \multirow[t]{2}{*}{ Ingredient } & \multirow[t]{2}{*}{$D M(\%)$} & \multicolumn{2}{|c|}{$\% D M$} \\
\hline & & $C P$ & $A D F$ \\
\hline Fish meal & 96.5 & 66.6 & 1.6 \\
\hline Meat meal & 97.9 & 59.7 & 6.1 \\
\hline Soybean meal & 92.5 & 53.5 & 5.6 \\
\hline Feather meal & 95.1 & 90.0 & 2.0 \\
\hline Canola & 93.7 & 41.2 & 19.4 \\
\hline Dried distiller's grain & 95.8 & 32.2 & 15.6 \\
\hline Barley & 92.1 & 12.7 & 6.9 \\
\hline Corn & 92.0 & 9.8 & 3.7 \\
\hline Rye & 91.9 & 10.6 & 3.7 \\
\hline Wheat shorts & 93.4 & 19.8 & 10.9 \\
\hline Soybean hulls & 93.2 & 11.0 & 48.4 \\
\hline
\end{tabular}


easy removal of particulate material without the seam holes being sealed. They were made from PeCap Polyester $\left.{ }^{(}\right)$(Thompson and Co Ltd, Montreal) with a pore size of $53 \mu \mathrm{m}$. Approximately $10 \mathrm{~g}$ of a sample (on a fresh basis) were placed in each bag, which was tied with a $30-\mathrm{cm}$ length of braided fishing line. During incubation, duplicate bags were clamped to a $600-\mathrm{g}$ weight which was tied to a $60-\mathrm{cm}$ long main line anchored outside the fistula. Incubation periods were $3,6,9,12,24,48$ and $72 \mathrm{~h}$, with all bags inserted in the rumen at the same time. Upon removal, bags were washed in cold water in a washing machine until the rinsing water was clear. Zero time disappearance values were obtained by washing non-incubated bags in a similar fashion. Bags then were dried in a forced-air oven at $55^{\circ} \mathrm{C}$ for $48 \mathrm{~h}$. Percentage disappearance of DM or TN was calculated from the proportion remaining in the bag.

Degradation of DM or TN was calculated using the equation of Orskov and McDonald (1979):

$$
p=a+b\left(1-e^{-c t}\right)
$$

where $p=$ percentage disappearance at time $t$, $a=$ the intercept representing the portion of DM or TN solubilized at time $0, b=$ the fraction of DM or TN that is potentially degradable in the rumen, $c=$ the constant rate of disappearance of fraction $b$, and $t=$ time of incubation. The nonlinear parameters $a, b$ and $c$ were estimated by an iterative least-squares procedure (Statistical Analysis System Institute Inc, 1985), and best-fit values were chosen by the Secant method (DUD) using the convergence criterion $\left(10^{-8}\right)$ of SAS (Statistical Analysis System Institute, Inc, 1985). The effective degradability of DM (EDDM) or TN (EDTN) is the amount that will actually be degraded in the rumen and was calculated using the following equation (Orskov and McDonald, 1979):

$$
\operatorname{EDDM} \text { or } \operatorname{EDTN}=a+\left(\frac{b c}{c+k}\right)
$$

where $k$ is the estimated rate of solid outflow from the rumen and the other parameters are the same as described above. Effective degradability of DM or TN was estimated for each ingredient assuming rumen solid outflow rates of
2,5 , and $8 \% / h$, which may be representative of low, medium, and high feed intake (Agricultural Research Council, 1984).

\section{Ruminal fermentation characteristics}

Rumen contents were sampled $(100 \mathrm{ml})$ at 0,1 , $2,3,4,5$ and 6 after feeding and the $\mathrm{pH}$ was determined immediately after collection. The samples were then stained through 2 layers of cheesecloth and $2 \mathrm{ml}$ of $0.5 \mathrm{M}$ sulfuric acid were added to $8 \mathrm{ml}$ of strained ruminal fluid to lower the $\mathrm{pH}$. Samples then were centrifuged at $16000 \mathrm{~g}$ and the supernatant was stored at $-20^{\circ} \mathrm{C}$ for VFA determination.

\section{Chemical analysis and statistical analyses}

Alfalfa and corn DM was determined according to the method of Dewar and McDonald (1961), and the DM of ingredients by oven-drying at 100 ${ }^{\circ} \mathrm{C}$ (Association of Official Analytical Chemists, 1990). Total $N$ of alfalfa, corn and feed ingredients was measured on fresh material by the Kjeldahl method. The procedures of Goering and Van Soest (1970) were used to determine ADF in feed ingredients. The VFA were determined by gas chromatography (Varian model 3400, Varian Can Inc, Ville St-Laurent, Quebec, Canada) using valeric acid as the internal standard. All results were subjected to ANOVA according to a randomized design using the general linear model procedure of the Statistical Analysis System Institute Inc (1985) with the proportion of concentrate in the diet being the only source of variation. Significant difference was established at $P<0.05$ unless otherwise noted.

\section{RESULTS AND DISCUSSION}

Ruminal characteristics of cows were affected by the proportion of concentrate (table II). Although there were only 2 repetitions per treatment, the results showed that cows fed the highest level of concen- 
Table II. Ruminal characteristics of dairy cows fed a low (LC) or a medium level of concentrate $(\mathrm{MC})^{1}$.

\begin{tabular}{lll}
\hline Item & Treatment \\
\cline { 2 - 3 } & LC MC \\
\hline
\end{tabular}

$\begin{array}{lrrr}\text { Rumen } \mathrm{pH}^{2} & 6.26 & 6.13 & 0.04 \\ \text { Total VFA }(\mu \mathrm{M} / \mathrm{ml}) & 91.00 & 89.55 & 1.23 \\ \text { VFA (mol/100 ml) } & & & \\ \text { Acetate (A) } & 71.79 & 69.84 & 0.24 \\ \text { Propionate (P) } & 18.81 & 18.89 & 0.10 \\ \text { Butyrate } & 9.39 & 11.17 & 0.86 \\ \text { A:P2 } & 3.81 & 3.68 & 0.04\end{array}$

${ }^{1}$ Least squares means with pooled SE, $n=2$ per treatment; ${ }^{2}$ effect of concentrate proportion $(P<0.05)$.

trate had lower values of $\mathrm{pH}$, total VFA, acetate, and acetate to propionate ratio. Rumen $\mathrm{pH}$ and the acetate to propionate ratio were significantly affected by the proportion of concentrate in the diet. A decrease in rumen $\mathrm{pH}$ can decrease DM degradability as a result of lower cell wall disappearance following starch feeding (Lindberg, 1981), thus decreasing microbial access to protein as cellulolysis is decreased. However, averaye rumen $\mathrm{pH}$ was close to the optimal range of 6.1 to 6.3 for ruminal proteolysis and deamination (Lewis and Emery, 1962).

The nonlinear estimation of $a, b$ and $c$ for DM degradability differed considerably among feed ingredients (table III). However, the estimates for each feed ingredient were generally similar for the MC and LC diets. The only differences were for feather meal and wheat shorts, which showed higher $b$ and $c(P=0.09)$ values respectively for cows fed LC than for those on MC. The EDDM of protein, energy and fiber sources was similar for both $M C$ and LC with EDDM2 of feather meal being the only form of degradability to be affected by the proportion of concentrate. The small differences observed between $M C$ and LC for EDDM of feed ingredients were possibly due to the narrow range of concentrate levels fed (40 vs 20\%) which were not large enough to allow differences to be significant. Significant differences in DM disappearance of protein sources have been reported for diets containing $20 \%$ compared to $80 \%$ concentrate (Barrio et al, 1985).

The nonlinear estimation of $a, b$ and $c$ and EDDM value of feed ingredients did not permit categorization of feed ingredients as sources of protein, energy or fiber due to the great variation among the means. For example, similar EDDM was observed for some sources of protein (canola and dried distillers) and energy (wheat shorts) while within protein sources, some values were very dissimilar (feather meal and canola).

The nonlinear estimation of $a, b$ and $c$ for total $N$, and EDTN values were more affected by the proportions of concentrate than those of the EDDM. Although not highly significant, the $b$ values of feather meal and rye tended to be higher $(P<$ $0.10)$ for LC than for MC. The only effect of proportion of concentrate on $c$ was for wheat shorts with a higher value being observed for LC than for MC. Level of concentrate also affected the EDTN of some feed ingredients. Within protein sources, feather meal and canola were less degradable at solid outflow rates of $2 \% / \mathrm{h}$ when cows were fed MC compared to LC. This is in agreement with the observations of Lindberg (1981) and Loerch et al (1983) who found that increasing proportion of grain decreased the EDTN of some protein sources but not others. Loerch et al (1983) and Weakley et al (1983) observed a linear decrease in EDTN of protein sources as the dietary grain proportion increased. The decrease in EDTN of protein sources incubated in the rumen of animals fed high 


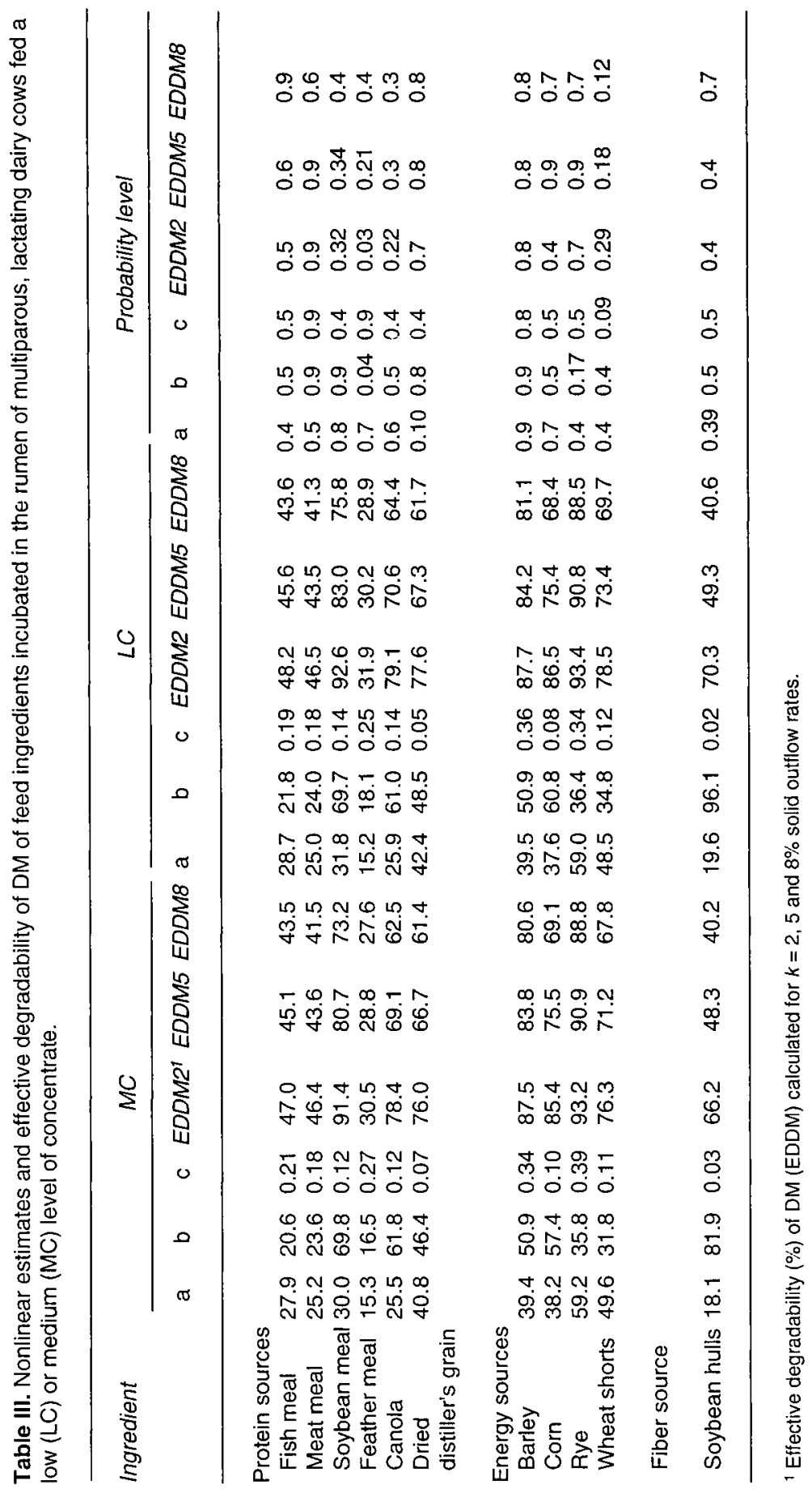


concentrate diets could primarily result from a decrease in rumen $\mathrm{pH}$ as observed in our experiment and by Loerch et al (1983), which could decrease either the number of proteolytic bacterial species or rumen protein solubility. Loerch and Berger (1980) observed that degradation of soybean meal was decreased by feeding high energy diets which decrease rumen $\mathrm{pH}$.

The EDTN of protein sources of plant origin was found to be higher when incubated in the rumen of sheep fed dried grass than when they received whole barley, while no difference was found for fishmeal (Ganev et al, 1979). Similarly, Barrio et al (1985) observed a greater disappearance of protein from both plant and animal sources when cows were fed 20 as compared to $80 \%$ concentrate. In this experiments there was no way of distinguishing the origin of the protein source (animal or plant) by the results obtained on either $M C$ or LC which agrees with the findings of Barrio et al (1985). No special pattern of EDTN for plant or animal proteins was found according to the diet fed. The differences observed among experiments regarding effect of proportion of concentrate on EDTN of protein sources might be related to the different basal diets fed and their effects on rumen $\mathrm{pH}$ and resulting microbial population (Lindberg, 1985).

The EDTN was similar for MC- and LCfed cows for the 3 grains (energy sources) which agrees with the results of Lindberg (1981). However, wheat shorts tended to have higher $(P<0.10)$ EDTN for LC than for $M C$ for the 3 values of $k$. There was a difference between $M C$ and $L C$ for the fiber source (table IV). For soybean hulls, EDTN at solid outflow rates of $k=0.05$ and $0.08 / \mathrm{h}$ was higher for cows fed LC than for those fed MC. The lower protein degradability of soybean hulls for cows fed MC compared to LC could be due to a decrease in cellulolytic bacterial numbers, as observed by Latham et al (1971) in animals fed high grain diets. Protein degradation of fiber source may decrease in parallel with cellulose digestion due to decreased protein exposure to proteolytic bacteria. This is corroborated by the linear relationship observed between degradability of cellulose and that of protein (Lindberg, 1985). According to Ganev et al (1979), the cellulosic material in fiber sources appears to afford some protective properties when fed with high concentrate diets resulting in decreased degradability of their proteins. However, Inoue et al (1989) found no effect of proportion of concentrate on degradability of forage protein. At each outflow rate, the EDTN varied among feed ingredients and was moderately but significantly affected in some cases by the diet fed to cows.

\section{CONCLUSION}

In conclusion, proportions of concentrate used in this experiment ( $20 \%$ vs $40 \%$ ) had some effects on $b$ and $c$ values of the equation of Orskov and McDonald (1979). Using different theoretical rumen outflow rates $(2,5$ and $8 \% / h$ ) representative of low, medium and high feed intakes (Agricultural Research Council, 1984) generally resulted in no effect of proportion of concentrate on the EDDM of feed ingredients, but modified the EDTN of some protein sources and that of the fiber source studied. The EDTN of grains was not affected by proportion of concentrate. The effect of proportion of concentrate on the EDTN of sources of protein and fiber could be important, since theoretical $k$ values are often used to determine protein degradability. However, no direct measurement of solid outflow rate was performed to confirm the theoretical observations. Although results obtained in this experiment were not always significant due to the limited number 
Degradability and concentrate proportion

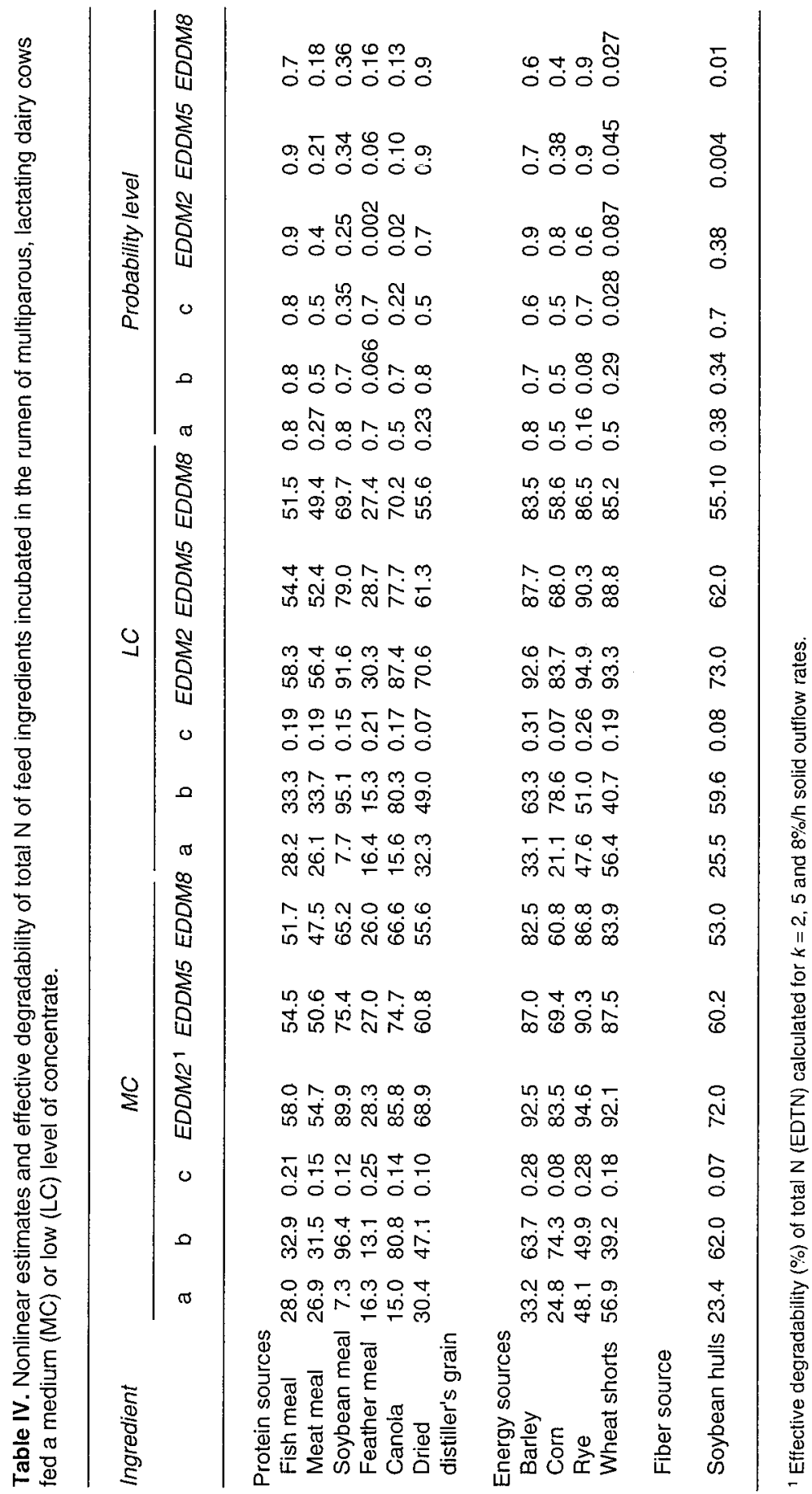


of repetitions per treatment, there was a definite trend toward decreased EDTN for sources of protein and fiber as the proportion of concentrate in the diet increased.

\section{ACKNOWLEDGMENTS}

The author wishes to thank $L$ Veilleux and $M$ Pelletier for their technical assistance, A Belleau for the statistical analysis and L Côté for preparation of the manuscript.

\section{REFERENCES}

Agricultural Research Council (1984) The Nutrient Requirements of Ruminant Livestock Suppl No 1. Commonweath Agricultural Bureau, Farnham Royal, UK

Association of Official Analytical Chemists (1990) Official Methods of Analysis. Washington, DC, 15th edn

Barrio JR, Owens FN, Goetsch AL (1985) Soluble nutrients in protein supplements and in situ disappearance. Can J Anim Sci 65, 667-672

Church DC (1984) Livestock Feeds and Feeding. O \& B Books Inc, Corvalis, OR, 2nd edn

Dewar WA, McDonald P (1961) Determination of dry matter in silage by distillation with toluene. J Sci Food Agric 12, 790-795

Ganev G, Orskov ER, Smart R (1979) The effect of roughage or concentrate feeding and rumen retention time on total degradation of protein in the rumen. J Agric Sci (Camb) 93, 651-656

Goering HK, Van Soest PJ (1970) Forage Fiber Analyses. USDA, Handbook No 379, Washington, DC
Inoue $\mathrm{Y}$, Nishida $\mathrm{R}$, Morita $\mathrm{Z}$, Oura $\mathrm{R}$, Sekine J (1989) Effect of concentrate to roughage on the rumen degradability of crude protein in Italian ryegrass and cubed alfalfa hays. AJAS $2,409-410$

Latham MJ, Sharpe ME, Sutton JD (1971) The microbial flora of the rumen of cows fed hay and high cereal rations and its relationship to the rumen fermentation. $J$ Appl Bacteriol 34 425-434

Lewis TR, Emery RS (1962) Intermediate products in the catabolism of amino acids by rumen organisms. J Dairy Sci 45, 1363-1368

Lindberg JE (1981) The effect of basal diet on the ruminal degradation of dry matter, nitrogenous compounds and cell walls in nylon bags. Roughage and cereals in varying proportion. Swedish J Agric Res 11, 159169

Lindberg JE (1985) Estimation of rumen degradability of feed proteins with the in sacco technique and various in vitro methods: a review. Acta Agric Scand suppl 25, 64-97

Loerch SC, Berger LL, Gianola D, Faney GC Jr (1983) Effects of dietary protein source and energy level on in situ nitrogen disappearance of various protein sources. J Anim Sci 56, 206-216

Orskov ER, McDonald I (1979) The estimation of protein degradability in the rumen from incubation measurements weighted according to rate of passage. J Agric Sci (Camb) 92, 499-503

Statistical Analysis System Institute Inc (1985) SAS User's Guide: Statistics. SAS Institute Inc, Cary, NC, version 5 edn

Weakley DC, Stern MD, Satter LD (1983) Factors affecting disappearance of feedstuffs from bags suspended in the rumen. $J$ Anim Sci 56, 493-507 